\title{
A Critical Analysis of the Educational Impact of Analytic Social Epistemology
}

\author{
Koichiro Misawa \\ School of Education \\ Tokyo University of Social Welfare, Japan
}

Received: April 28, 2012 Accepted: June 11, 2012 Published: August 1, 2012

doi:10.5296/jse.v2i3.1729 URL: http://dx.doi.org/10.5296/jse.v2i3.1729

\begin{abstract}
Social epistemology is now a thriving field of intellectual inquiry. In this paper, I examine the scope and limits of the kind of social epistemology that accrues from the (post-)analytic context in Anglophone philosophy. A remarkable feature of this sub-discipline relates to education in respect of its subject matter. Ironically, however, this paper reveals that analytic social epistemology has not yet made a salient contribution to advancing discourses relating to education. For there is something unsatisfactory about the three ideas that constitute analytic social epistemology as a sophisticated philosophy of testimony: normative naturalism, externalism in epistemic justification, and reliabilism. This paper therefore points to a basic flaw in each of these three notions and ends with the tentative suggestion that a "sociological" social epistemology may prove a corrective to analytic social epistemology —in such a way as to have a more direct bearing on discourses on social practices like education.
\end{abstract}

Keywords: Social epistemology, Testimony, Normative naturalism, Externalism in epistemic justification, Reliabilism 


\section{Introduction}

It would be absurd to suppose that the history of intellectual inquiry had never witnessed those who were concerned with the social dimensions of knowledge until the term "social epistemology" was coined. I have no ambition to do a thorough historical survey of the social aspects of knowledge. Rather this paper aims simply at evaluating the contribution that "social epistemology" has made to the discourse in the philosophy of education in particular and education studies in general.

There are two paradigmatic academic enterprises prompted under the flag of "social epistemology" which I think shed intriguing light on existing theories of knowledge in such ways that they have a direct bearing on the thinking about social practices like education-one is philosophical and the other is sociological. ${ }^{1}$ Put more concretely, the philosophical one has come to the fore in analytic philosophy, hence the title "analytic social epistemology"-its representatives being Alvin Goldman and Philip Kitcher; whereas the sociological one has been heralded chiefly by the versatile sociologist Steve Fuller, which might be seen as a present incarnation of the sociology of knowledge. Noteworthy here is that both of these social epistemologies recognize education as a main subject matter to be addressed within their respective frameworks for "social epistemology."

Social epistemology is then gradually becoming accepted as a legitimate topic of inquiry in the philosophical study of education (e.g. Ritola, 2011). Yet, in my view, the two social epistemologies mentioned above, as we shall see, both (intentionally) underestimate the mutually dependent parts of a single complex totality of human knowledge. Therefore, to appreciate the mutually dependent parts and thereby develop a more nuanced approach to thinking about the social dimensions of knowledge as well as of its bearing on educational discourse precisely forms the focus of this paper, although, for the reason below, the primary attention is focused on examining the scope and limits of analytic social epistemology.

To achieve this purpose, it is necessary to elaborate the context in which analytic social epistemology has figured. (It may arouse the suspicion that the "educational impact" of analytic social epistemology is not the direct focus of the arguments that follow. Still, a scholarly discussion of that context is the essential preliminary for assessing the prospects for the educational relevance of analytic social epistemology.) Three remarkable features that inform analytic social epistemology are (i) a commitment to naturalism (which can be called "normative naturalism" as opposed to Quinian stronger naturalism), (ii) an externalist view (in the internalism/externalism distinction in epistemic justification), and (iii) a truth-oriented epistemology (in the form of reliabilism). This paper thus explores these three themes that weave together the central theses of analytic social epistemology, which is partly elucidatory and partly critical. This paper concludes with a tentative suggestion that a "sociological" social epistemology may be a corrective to analytic social epistemology in such a way as to enable a detailed analysis of the institutional structures relevant to the formation and

\footnotetext{
${ }^{1}$ Attention here is confined to the research programs that name themselves "social epistemology.” Needless to say, there are forms of philosophical thinking and sociological research that are concerned with the social dimensions of knowledge.
} 
transmission of knowledge that occupy a central place in discussions of education.

\section{Two Paradigmatic Social Epistemologies}

Given that there are deep tensions between analytic social epistemology and Fuller's "sociological" social epistemology and that they are each liable to underestimate their opponent insights respectively, the purpose of this paper would be best served by a full-fledged comparison of these two programs. However, space here does not permit me to fully expound these two social epistemologies. So, in this paper, I will devote myself to examining the work of the philosophical social epistemology.

Before expanding on an elucidation and critique of analytic social epistemology, however, it would be of service to delineate the contours of both analytic and Fuller's social epistemologies. Fuller's characterization, while being slightly simplistic, serves this purpose.

These two social epistemologies stand in marked contrast to each other concerning the two component parts of "social epistemology"-namely, the "social" and "epistemology." What is meant by the "social" in analytical social epistemology is meant in the broadest sense; i.e. it is a social epistemology in the sense that it concerns more than one person in relation to philosophical inquiry into how the subject knows something. In other words, analytic social epistemology has developed from an awareness that epistemic subjects obtain knowledge through the testimony of others. By contrast, in Fuller's social epistemology, based upon a number of sociological perspectives, "social” directly designates society; i.e. it grapples with how knowledge is formed, distributed and consumed in the wider community. This difference vis-à-vis the "social" in social epistemology has to do with the ways these two social epistemologies approach "epistemology.” As Fuller (2007) puts it, while analytic social epistemology's concern is with investigating the verb "to know" and thus employs what Fuller calls the "inside-out strategy" (i.e. how individuals know something), Fuller's social epistemology is concerned with the noun "knowledge" and thereby handles the "outside-in" strategy (i.e. how knowledge is created, transmitted and utilised in a society) (pp. 177-8).

This characterization of Fuller's surely provides a useful typology of the two varieties of social epistemology, serving as a helpful supplement to the following, more detailed scrutiny of the features of analytic social epistemology.

\section{Three Remarkable Features of Analytic Social Epistemology}

\subsection{Normative Naturalism}

The second quarter of the 20th-century already witnessed Heidegger's radical overcoming of traditional philosophy and Wittgenstein's therapeutic farewell to it. But it is W. V. O. Quine who decisively set the direction in which Anglophone analytic philosophy in a narrow sense has since moved. Quine's influential work involves a turning away from the logical analysis of the relations among propositions believed by the subject toward a program of what is called naturalistic epistemology. In "Epistemology Naturalized” (1969), the locus classicus in this area of inquiry, his aspirations to ground a naturalism in epistemology are carried to their extreme: Quine (1998) asserts that epistemology "simply falls into place as a chapter of 
psychology and hence of natural science” (p. 24, italics added). This line of thinking inclines us to "[leave] aside questions of justification and considers only the genetic, causal question." (Dancy, 1985, p. 235, italics added). Put another way, Quine urges that philosophers stop the dream of the traditional First Philosophy-i.e. the craving to deduce science from the subject's observations, namely from the given sense data. ${ }^{2}$ In this way, Quine "undermined the last vestiges of First Philosophy and strongly endorsed the continuity between philosophy and science" (De Caro and Macarthur, 2004, p. 8). This view has been so influential that today "scientific naturalism is the current orthodoxy, at least within Anglo-American philosophy.” (Ibid., p. 1)

The effect of naturalistic epistemology is pervasive. It is highly questionable, however, whether anyone has ever really practically adhered to a naturalistic epistemology in the strict sense. This is simply because we can never replace normative justification with scientific description insofar as what enables the conducting of the sciences is already embedded in something normative. That is, scientific description is not a direct, thoroughgoing mirror or representation of what occurs in the "natural" world. There is no obliterating such cognitive dimensions in scientific investigations. ${ }^{3}$ Thus, there does not seem to be any place for what is sometimes called "non-normative naturalism"4 that excludes justification from view. This would lead us to the observation that:

If we locate the split between Quine and traditional epistemology at the descriptive vs. normative divide, then currently influential naturalism in epistemology is not likely to fall on Quine's side. (Kim, 2000, p. 310)

A prominent form of naturalism that makes scientific naturalism "the current orthodoxy" is not the Quinian kind of naturalism, but what may be called "normative naturalism." Normative naturalism has its variants. But the primary motivation for such studies is to accommodate two features which cannot be encompassed either by traditional epistemology or non-normative naturalism: i.e. the normative aspect (the preservation of the notion of justification) and the appeal to scientific means. The focus below will be on two features of the strand that broadens its scope toward a "social epistemology": externalism and reliabilism.

\subsection{Externalism}

Naturalistic epistemology encourages a predisposition toward externalism in epistemic justification. Externalism has been a focus of a great deal of work over the last decades, but, as Laurence BonJour (2002) says, until very recently internalism took center stage for long in

\footnotetext{
${ }^{2}$ Quine (1981) argues elsewhere that "Naturalism does not repudiate epistemology, but assimilates it to empirical psychology. Science itself tells us that our information about the world is limited to irritations of our surfaces, and then the epistemological question is in turn a question within science: the question how we human animals can have managed to arrive at science from such limited information. Our scientific epistemologist pursues this inquiry and comes out with an account that has a good deal to do with the learning of language and with the neurology of perception” (p. 72, italics added).

3 As Catherine Elgin (2006) tersely claims, "[s]cience has to select, organize, and regiment the facts to generate....an understanding. It needs criteria for selection, organization, and regimentation.” (p. 204).

$4 \quad$ See e.g. Siegel (1996).
} 
epistemology (p. 221). He (1992) provides a lucid explanation of internalism and externalism in a relevant context:

A theory of justification is internalist if and only if it requires that all of the factors needed for a belief to be epistemically justified for a given person be cognitively accessible to that person, internal to his cognitive perspective; and externalist, if it allows that at least some of the justifying factors need not be thus accessible, so that they can be external to the believer's cognitive perspective, beyond his ken. (p. 132, italics in original)

The externalist aims to combat the threat faced by the internalist. The externalist tries to dislodge the perennial question of how to account for the "external" world and other minds from a first-person's point of view, by putting forward the thesis that "the epistemic justification or reasonableness of a basic empirical belief derives from the obtaining of an appropriate relation, generally construed as causal or nomological in character, between the believer and the world” (BonJour, 1985, p. 34).

In the traditional internalist's eyes, however, the externalist puts the cart before the horse, for external factors that are supposed to be explained from a first-person's cognitive state are unduly presupposed from the outset in externalism. Viewed from the standpoint of the externalist, on the other hand, externalism can avoid the seemingly silly skepticism that internalism easily invites. Such skepticism always lurks in the internalist scheme, inasmuch as we cannot expel the possibility that a belief fully justified in one's mental state nonetheless has nothing to do with truth. Roderick Chisholm (1989) encapsulates this point:

According to this traditional conception of "internal" epistemic justification, there is no logical connection between epistemic justification and truth. A belief may be internally justified and yet be false. This consequence is not acceptable to the externalist. He feels that an adequate account of epistemic justification should exhibit some logical connection between epistemic justification and truth. (pp. 76-7, italics in original)

Whether or not externalism counts as the most plausible account of knowledge depends on how well it captures the conceptions of truth and reality. This is where naturalistic epistemology enters the picture. It has a great affinity with externalism. ${ }^{5}$

Naturalism in epistemology is "a methodological position that is quite naturally suggested by externalism” (Greco, 1999, p. 12). Since the externalist thinks epistemological questions cannot be resolved only by speculative reflection in armchair fashion, she calls for the aid of empirical means to answer those questions. In this way, the externalist approaches naturalistic epistemology as a result of abandoning "armchair philosophy."

\subsection{Reliabilism}

Of the many externalist views in epistemic justification, reliabilism acquires a certain

\footnotetext{
5 Although, in most cases, externalism and naturalized epistemology are advocated by the same philosophers, they are not identical views (BonJour, 2002, p. 253). However, the point here is that, as a consequence of discarding internalism, externalism has a clear tendency to draw on scientific means to construe the "external” world.
} 
salience. ${ }^{6}$ This view is extended toward a "socialization" of epistemology by Goldman, Kitcher, and others. I thus outline what Goldman calls "process reliabilism.”

The central thrust of reliabilism, as the name indicates, is that "what makes a belief justified is the cognitive reliability of the causal process via which it was produced, that is, ...that the process in question leads to a high proportion of true beliefs, with the degree of justification depending on the degree of reliability” (BonJour, 2002, pp. 226-7, italics in original). This stands in contrast to internalism to the extent that reliabilism does not require that the believer in question has any sort of cognitive awareness of the reliability of the belief-producing process in order for her to be justified (Ibid., p. 227).

As intimated earlier, Goldman repudiates the Quinian kind of naturalism due in large part to its inappropriate disregard for the normative dimensions of knowledge that inform traditional epistemology. This is not to mean, however, that Goldman stands in harmony with the internalist thesis that the matter of normativity can be approached only through one's own internal reflection. Rather he puts forward the idea that the germ of the normative elements is present in the belief-generating processes. To put this more clearly, the normative status of belief-forming processes consists, on Goldman's view, in true beliefs produced by those processes. Hence his moderate naturalism is formulated as "process reliabilism," which devotes attention to how reliable given belief-forming processes are in the light of truth. To borrow his own words (1998), “justified beliefs are ones produced by belief-forming processes with high truth-ratios” (p. 445). Obviously, one conspicuous hallmark of this line of thought is its peculiar aspiration for truth. For the notion of reliability presupposes the notion of truth; put the other way round, the notion of reliability does not make any coherent sense without the notion of truth. Thus, in Goldman's scheme, the ground of the normative derives from the truths shown by scientific investigations such as cognitive science. Goldman prefers to call this sort of truth-oriented reliabilism "veritism." In this way, he mediates the natural and the normative, which non-normative naturalism is liable to disregard.

Two basic principles Goldman adduces in his formulation of moderate naturalism clarify the way in which the natural and the normative are mediated in his picture (2002):

(A) All epistemic warrant or justification is a function of the psychological (perhaps computational) processes that produce or preserve belief.

(B) The epistemological enterprise needs appropriate help from science, especially the science of the mind. (p. 26)

He goes on to argue that the thesis "(A) fits with the rather minimal metaphysical point that epistemic agents are natural phenomena, namely, physical organisms” (ibid., italics added).

The descriptions so far have provided the general framework within which a prominent form of naturalistic epistemology figures as a certain improvement to some part of non-normative naturalism. As will be discussed in the last section, this kind of normative naturalism also involves its own set of problems. Nevertheless, indeed, it engenders a new vista for

\footnotetext{
6 Amongst the externalist variants, reliabilism "has been perhaps the most widely discussed and advocated" (BonJour, 2002, p. 226).
} 
epistemology in a way that makes epistemology "socialized" through naturalized epistemology. (Iseda, 1997). Epistemology thereby can be brought to bear on the matters of social practices like education. The next section is thus concerned to provide a glimpse of this type of social epistemology.

\section{Analytic Social Epistemology}

The reason why this kind of social epistemology is pursued intensively in the Anglophone analytic tradition is not because this tradition takes precedence over other philosophical traditions in the recognition of the social nature of knowledge but for exactly the reverse reason. Steve Fuller (2007) points out that:

Accounts of knowledge in the other traditions already presuppose a social dimension, which would make social epistemology superfluous. For example, from the nineteenth century onward, epistemologies descended from French positivism and German idealism have consistently stressed the systematic and collective character of knowledge. In contrast, analytic philosophy has remained wedded to the Cartesian individual-now occasionally presented as Darwinian - as the paradigm case of the knower. In that respect, "social epistemology" is designed to redress the individualist bias of analytic philosophical accounts of knowledge. (p. 1)

The Anglophone epistemological tradition of philosophy has been marked by an individualist bent. The focal point is therefore the way in which and the extent to which analytic social epistemology based upon a naturalized epistemology can move beyond the individualist inclination of the tradition in which it originates. Earlier, I wrote that analytic social epistemology is a "social" epistemology in that it focuses on the testimony of others in the subject's acquisition of knowledge. Once some light is thrown on the testimony of others, it is clear that more than one person becomes the subject of research. ${ }^{7}$ Given that " $[\mathrm{t}]$ he most inclusive sense of the social is simply any relationship among two or more individuals" (Goldman, 2006), the social epistemology under consideration is worthy of the name of social epistemology. The central preoccupation of analytic social epistemology is then with investigating the reliability of the testimonial processes against the standard of truth-by means of scientific methods such as empirical psychology and/or theories of probability such as the Bayesian approach.

Yet, the argument for this social epistemology requires a footnote. For Goldman draws an unhelpful distinction between individual epistemology and social epistemology. According to him, belief-forming processes entail two types: cognitive and social processes. Cognitive processes are concerned with how a person reaches a belief; on the other hand, social processes are unavoidably concerned with more than one subject. Accordingly, two modes of epistemology, Goldman argues, are needed: individual epistemology and social epistemology.

\footnotetext{
${ }^{7}$ Philip Kitcher (1994), another leading protagonist of analytic social epistemology, expounds why analytic social epistemology is social: "[T]he exact point at which epistemology becomes social is in the appreciation of the possibility that whether or not a subject is justified (or whether or not a belief-forming process counts as reliable in the pertinent sense) turns on the properties of other people or of the group to which the subject belongs” (p. 113).
} 
Goldman assigns them the following roles:

Individual epistemology would identify and evaluate psychological processes that occur within the epistemic subject. Social epistemology would identify and evaluate social processes by which epistemic subjects interact with other agents who exert causal influence on their beliefs. The communicational acts of other agents and the institutional structures that guide or frame such communal acts would be prime examples of social-epistemic practices that would be studied within social epistemology. (Goldman, 2006)

This seems an indication that it never crosses Goldman's mind that "psychological processes that occur within the epistemic subject” are, in some sense, already social.

One of the criticisms made of analytic social epistemology is that analytic social epistemology is not social enough. This complaint is made by a lot of would-be more "social" social epistemologists who find their inspiration in the work of, say, anthropology, the sociology of knowledge or the history of science. To grasp the way that analytic social epistemology dissociates itself from other more radical social epistemologies including Fuller's one, it will help to focus on Kitcher's "Contrasting Conceptions of Social Epistemology” (1994), ${ }^{8}$ in which a somewhat caricatured and pejorative tone toward the rival conceptions of social epistemology can be found. ${ }^{9}$

The most regrettable connotation the term "social epistemology" may take on is the relativistic one: e.g. social epistemology is easily associated with the crude idea that the standards of knowledge vary from society to society. It is precisely this sort of relativistic image from which analytic social epistemology differentiates itself and which it imputes to other more "radical" variants of social epistemology. Thus, Kitcher enumerates the following three conditions as "the elements of a minimal social epistemology"-i.e. analytic social epistemology underpinned by reliabilism:

(1) Individuals are the primary subjects of knowledge. To ascribe knowledge to a community is to make an assertion about the epistemic states of members of the community.

(2) $\quad X$ knows that $p$ if and only if (a) $X$ believes that $p$ and (b) $p$ and (c) $X$ 's belief that $p$ was formed by a reliable process.

(3) The reliability of the process that produces $X$ 's belief that $p$ depends on the properties and actions of agents other than $X$. ( p. 113)

Some conspicuous traits that characterize analytic social epistemology can be detected in this formulation. First, (1) shows that analytic social epistemology still runs on an individualist track to the extent that "the primary subjects of knowledge are individual human beings" (ibid.), as opposed to “collective knowledge.” However, this individualist disposition of analytic social epistemology is not, Kitcher claims, tantamount to individualism in the classical Cartesian model. The watershed that divides them is whether to accept "some

8 Unless otherwise indicated, all citations from Kitcher in this section will be from this work.

9 Although Kitcher and Goldman share central thrusts constituting a reliabilist version of social epistemology, Kitcher pays more attention to "the collective epistemic goal” than Goldman does. (Kitcher, 2002, pp. 198-9). 
presuppositionless [i.e. Archimedean] point from which we can begin inquiry” (p. 112). Kitcher thus asserts that: "Social epistemology begins at the point of rejecting the individualistic reduction” (ibid.). Put another way, on Kitcher's conception, analytic social epistemology fully recognizes the existence of the engaged intellect. Second, (2b) reflects analytic social epistemology's strong aspiration for an epistemically independent reality-i.e. the world as it really is, so to speak. ${ }^{10}$ Third, (2c) and (3) display a reliabilist account of the formation of beliefs, which is pertinent to analytic social epistemology's embracing of a naturalistic and externalist account of knowledge.

Espousers of other more radical social epistemologies dispute analytic social epistemology by claiming that the formulation above exemplifies a continuation of traditional epistemology. Kitcher himself is aware of this line of criticism:

I suspect that the project I have sketched seems almost indistinguishable from classical epistemology ("positivism”) to those like Bruno Latour, Donna Haraway, Andrew Pickering, Sharon Traweek, and the many others in sociology, anthropology, and history of science who want to develop a more radical critique. (p. 131)

The main criticisms made of the manifested conditions of analytic social epistemology above are, in short, directed against (1) — i.e. methodological individualism —and (2b) —i.e. the idea of an epistemically independent reality. As Kitcher admits, more radical social epistemologies are fundamentally antithetical to the individualist and realist character of analytic social epistemology:

[Analytic social epistemology] slights the social by making the most individualistic parts of social science-psychology, microeconomics - central to the development of social epistemology. If we [more radical social epistemologists with whom Kitcher does not have affinity] were to start, instead, with sociology, political theory, or cultural anthropology as our paradigms of social science, we might develop a far more social social epistemology. (p. 116, italics in original)

The basic aim of more radical versions of social epistemology is to develop collectivity-based accounts of human knowledge as opposed to the traditional individualist approach.

Yet, for Kitcher, the above charge made of analytic social epistemology does not provide any reason for embracing the idea that "the phenomena that inspire the "multiple embodiments" approach to knowledge really demand a break with the traditional conception of knowledge as something that is located in (or possessed by) an individual subject" (p. 118). He goes on to claim that "the sociologizing program based on the rejection of (1) seems headed either for relativism or for vagueness" (p. 119). ${ }^{11}$ The temptation to dismiss the conventional view that the primary epistemic subject is the individual, Kitcher expounds, seduces us to abandon the

${ }^{10}$ Even if (2b) is to be understood simply to imply that $p$ is true, that does not seem to defuse the fear that will be described in the final section.

11 Kitcher adduces three exemplars that are frequently used to give theoretical endorsement to more radical social epistemologies: (i) "the Strong Programme in the sociology of knowledge"; (ii) "the venerable anti-realist attack on the correspondence theory of truth"; and (iii) "a thesis about the underdetermination of our claims about reality by our encounters with reality” (p. 120). 
traditional presumption of truth as “epistemically independent"-i.e. to use his formulation above, the rejection of (1) is driven towards that of (2b). It is this familiar unnerving issue that differentiates Kitcher's favored "more limited conception of social epistemology” (p. 115) from versions of "more social social epistemology":

Traditionalists suppose that the notion of truth is epistemically independent, that we are not to reduce the notion of truth in terms of what people know, or believe, or what the members of a society accept. Precisely this epistemic independence of the concept of truth inspires the radical versions of social epistemology to break with tradition. (pp. 119-20)

It is clear that the contrast Kitcher establishes between radical social epistemologists and analytic social epistemologists is founded on a familiar epistemic/non-epistemic dichotomy concerning the concept of truth-i.e. involving a dualistic split between the idea, on the one hand, that reality as it is is totally independent of humanity and, on the other, that the human mind constitutes realities. This misleading dichotomy has a disturbing consequence in terms of the effect of analytic social epistemology on the mainstream of educational discourse.

\section{The Bearing of Analytic Social Epistemology on Issues of Education}

Analytic social epistemology has carved out a path to deal with a broad range of social practices which had no proper place, qua subject matter, in traditional epistemology — such as science, law, democracy and education (to give Goldman's examples). As mentioned earlier, however, even while fully respecting the point that education comes under the scope of serious epistemological discourse, I suspect that analytic social epistemology has not yet had a great impact on the discourse in the philosophy of education nor has it made much contribution to the philosophical analysis of educational practices. Therefore, I here draw attention to how education is addressed within the framework of analytic social epistemology by reference to Goldman's discussion of education, for he devotes ample attention to education as an important subject falling into the province of social epistemology (Goldman, 1999).

Goldman's views on education, however, appear little more than "a traditional picture of what education is all about, one aligned with an 'Enlightenment' conception of epistemology” (Goldman, 1999, p. 349). Goldman (1998) claims, for example, that:

The fundamental aim of education, that is, of schooling systems at all levels, is to provide students with knowledge and to develop intellectual skills that improve their knowledge-acquiring abilities. This, at any rate, is the traditional image, and I know of no good reason to abandon it. (p. 439)

Goldman's views obviously resonate with those of the proponents of the Enlightenment's vision of education such as Harvey Siegel in fundamental respects. In fact, Siegel (2005), in his paper on Goldman's approach to education, describes their debate as "an in-house dispute" (p. 347). No problem arises from Siegel's basic ideas on education at the formal level-the idea that fostering the ability to appreciate knowledge, rationality and justification (in relation to critical thinking) plays an educationally important part. Yet, trouble immediately arrives once this is confused with an idea that identifies the currently dominant 
view of the world as the only description of it.

Indeed, Goldman takes care to prevent a likely misunderstanding that analytic social epistemology's argument concerning education is no more than, say, that of Robert Hutchins's "essentialism" with regard to a core curriculum - the view that "[e]ducation implies teaching. Teaching implies knowledge. Knowledge is truth. The truth is everywhere the same. Hence education should be everywhere the same” (Goldman, 1998, p. 442). In short, analytic social epistemology, Goldman is telling us, in no way precludes multiculturalism. On Goldman's picture, furthermore, it can even bear on several domains that are prima facie inharmonious with veritistic value such as education in art, literature, and history, by raising awareness of "secondary judgements" comprised of the expertise of experts in those domains. For example, analytic social epistemology, emphasizing the roles of testimony and trust in the transmission of knowledge, motivates raising the questions such as the following: "What kinds of education...could substantially improve the ability of novices to appraise expertise, and what kinds of communicational intermediaries might help make the novice-expert relationship more one of justified credence than blind test?” (Goldman, 2002, p. 60)

There is surely an insight in analytic social epistemology's approach to education, which is worth further deepening. However, it is dubious whether analytic social epistemology fully develops in the ways it promised, when it comes to the analysis of education. Goldman (1999) envisages social epistemology as "linked to those social science and policy disciplines that study knowledge in its social and institutional contexts” (p. ix). The way Goldman grapples with educational issues by recourse to analytic social epistemology, nevertheless, seems far from satisfactory to the extent that it has not delved deeper into the analysis of the institutional structures or the organized forms of knowledge that guide or mold the ways knowledge is formed and transmitted. Nor has it attempted a more fine-grained exploration of an interdisciplinary development in the investigation into educational issues. The primary obstacle that stands in the way of a more fruitful development of analytic social epistemology in these respects resides, in my view, in the perennial individualist tendency that has bound analytic philosophy - the self-imposed adherence to the inquiry into how the subject knows something with little reference to the conditions which make it possible for her to have a particular kind of knowledge. The price for this is to miss the extent to which human beings as the engaged intellect, not as a merely biological species, can affect the conditions for knowledge that bear on what should count as knowledge (for a relevant argument, see Misawa, 2011). (It is to be remembered here that Goldman's view is that "epistemic agents are natural phenomena, namely, physical organisms.”)

In the next section, I highlight the sense in which analytic social epistemology is generally still anchored in the narrower sense beloved of analytic philosophy and thereby takes "social epistemology" back a step contrary to its attempt to "socialize" epistemology. To do this, I reveal the limits of the three features via which traditional epistemology is transformed into a social epistemology: normative naturalism, the internalism/externalism distinction, and reliabilism. The transformational process is not, in my view, as straightforward as proponents of analytic social epistemology may assume. 


\section{Objections to Analytic Social Epistemology}

\subsection{In Criticism of Normative Naturalism}

First of all, what is meant by "normative" in normative naturalism remains quite ambiguous. Such a suspicion is reinforced by an illustration of the salient aspects of normative naturalism by Robert Almeder (1998):

Alvin Goldman has argued for this second form [normative naturalism] which allows for traditionally normative elements but is "naturalized" for the reason that the practitioners of natural science, especially biology and psychology, will have the last word on whether anybody knows what they claim to know. ... Unlike the first form of naturalized epistemology [non-normative naturalism], this form allows traditional epistemology to sit in judgment on the deliverances of natural science, but....the judgment must be made by the practitioners of natural science using the methods of natural science. (p. 5, italics added)

If the central thrust of normative naturalism is along the lines of argument canvassed here, then that seems to show that normative naturalists miss the point in much the same way as non-normative naturalists fail to acknowledge that the normative is always immanent in some sense in doing the natural sciences. This sort of limited understanding of the normative is correlated with analytic social epistemology's idiosyncratic aspiration for truth based on reliabilism, which I shall revert to later.

\subsection{In Criticism of the Internalism/Externalism Dichotomy}

Second of all, the internalism/externalism distinction might be a mere remnant of the narrower sense of analytic philosophy's adherence to the Cartesian individual as the paradigm case of the knower. Even if the externalist (and the reliabilist) has striven to repudiate the model of the isolated thinker by foregrounding interpersonal testimony, that, it seems, has yet to attenuate its deep-rooted attachment to individualism. As Fuller (2007) sees it, the thriving debate on the distinction between internalism and externalism does not appear to be productive:

Regarded from outside the Anglophone world, it must be striking that internalism and externalism are seen as irreducible alternatives and not complementary components of a comprehensive theory of knowledge. (p. 2)

Internalism and externalism are complementary and they are so interlocking from the very beginning that it is almost pointless to think of internalism and externalism separately, let alone regard them as adverse to each other.

Given the remaining tendency of analytic social epistemology toward the individualist approach, it is no accident that the following parallel dichotomy is also working in the discussion of social epistemology. That is:

Analytic social epistemology also tends to see the individual and the collective as alternative sources of epistemic authority. (ibid.)

I cannot resist the temptation to say that these dichotomies cast a heavy shadow on the further 
development of analytic social epistemology. The fact is that as the ideas of internalism and externalism in epistemic justification are interpenetrating $a b$ initio, so are those of individualism and collectivism with regard to the primary epistemic subject. Its full implications put us in a position to recognize the concept of "the properly socialized individual” whose significance analytic social epistemology tends to diminish. This concept discredits Goldman's attempt to divide epistemology into individual and social epistemologies - the division that is in effect redundant insofar as the sociality of knowledge forms an integral part of epistemology. This is not to mean, however, that the notion of subjectivity loses its force. What seems missing from analytic social epistemology's picture is the importance attached to the socio-genetic dimensions of human knowledge. Rather, proponents of analytic social epistemology appear to remain trapped in the dispute between radical constructivism and realist positivism that are no longer really in dispute.

\subsection{In Criticism of Reliabilism}

Last but not least, there seems to be something suspect about the reliabilism on which analytic social epistemology heavily draws as a sophisticated philosophy of testimony. This has to do with the issues of truth and normativity. (Recall that the ground of the normative, on the conception of analytic social epistemology, derives from truth.) For the notion of reliability does not make sense without the notion of truth: i.e. the notion of reliability presupposes the notion of truth.

Robert Brandom is quite vocal in his doubts about reliabilism. In "Insights and Blindspots of Reliabilism," he (2000) formulates the gist of reliabilism as follows: "[A]ssessments of reliability (and hence of knowledge) can turn on considerations external to the reasons possessed by the candidate knower himself" ${ }^{\prime 2}$ (p. 120, italics added). Brandom's formulation motivates raising one vital question: What is the background against which reliability counts? The anticipated answer is, of course, "objective probabilities." But how can we reach knowledge about objective likelihood? The reliabilist's answer must be: "By scientific means" (because reliabilism is a naturalistic epistemology). In this way, as Brandom puts it, reliabilism needs "a naturalistic story about objective likelihood" (p. 111). Still, this is an aporia. For "objective probabilities are a staple of explanations in the natural sciences, indeed, even in fundamental physics” (p. 112). In a nutshell, Brandom claims that:

The reliability of the belief-forming mechanism (and hence the status of its true products as states of knowledge) varies depending on how we describe the mechanism and the believer. (p. 116)

In a word, “[a]n objective probability can be specified only relative to a reference class" (p. 112). ${ }^{13}$ To be sure, there are cases where we can arrive at knowledge, which can be

\footnotetext{
12 As mentioned, reliabilism is an externalist approach. This means that, in the justification of our beliefs, the subject does not need to know her belief-forming processes as long as the processes are reliable with high-truth ratios. Unless otherwise indicated, all citations from Brondom in this section will be from this work.

13 To use a longer passage from Brandom: "Relative to a choice of reference class, we can make sense of the idea of objective probabilities, and so of objective facts about the reliability of various cognitive mechanisms or processes-facts specifiable in a naturalistic vocabulary. But the proper choice of reference class is not
} 
explicable not through reasons but through reliability-i.e. the believer does not hold reasons for thinking she has reliable knowledge (which Brandom is willing to accept). Yet, this does not entail that we are free from all games of (what Brandom calls) "giving and asking for reasons"; that is, we are, as long as we live qua humans, involved in a game of applying concepts rather than simply drawing on concept-independent reliability. The fact that something serves in local cases does not guarantee that it suffices in global cases. To borrow a phrase from Brandom:

Besides serving as a kind of reason, reliability can take a subordinate place alongside reasons in certifying beliefs as knowledge. But it cannot displace giving and asking for reasons from its central place in the understanding of cognitive practice. (p. 110)

In brief, what is missing in the reliabilist theory is the insight that the notion of reasonableness is presupposed in reliabilism. Reliabilism's attention is exclusively focused on truth alone without special regard to its relation to reasons and reasonableness. Brandom is not the only philosopher who calls into question the usefulness of the notion of reliability. For example, Hilary Putnam (2004) argues that:

Judgments of reasonableness simply do not fall into classes to which we are able to assign probabilities. (Moreover, any scientific judgment can be regarded as having been arrived at by a virtually infinity of different "methods." "Reliabilism" only pretends not to presuppose the notion of reasonableness. (p. 143, italics in original)

The criticisms of the three central components of analytic social epistemology thus far demand a reconsideration of their fundamental presuppositions concerning truth and reality, especially in relation to human conceptual engagement with the world that brings out the essence of human beings as "socialized individuals." As touched upon, most proponents of analytic social epistemology vindicate the idea of "correspondence," while repudiating the traditional correspondence theory of truth. I here want to examine Kitcher's preferred view, "real realism," which is presented as opposed to what he pejoratively dubs "IRA"-Inaccessibility of Reality Argument.

It is true that Kitcher's "real realism” is a sophisticated version of the correspondence theory of truth insofar as it aims to bring "the observers" into the picture. It runs as follows:

There are referential relations between elements of representations and entities that are typically independent of the subject who has/uses the representation. These referential relations, together with the state of reality, jointly determine the truth values of statements and the accuracy values of other forms of representations (such as maps, diagrams). (Kitcher, 1994, p. 123)

This description of reality and truth is acceptable. Still, I am motivated to raise a concern as to whether real realism goes in the wrong direction when facing the questions Kitcher asks: "Why should the relations between the subject, the subject's representations, and the independent objects depend on the presence of another to note them? Why should the 
presence of an observer affect the connection between accurate representation and success? Why should the case of any of us — or of all of us — be any different?" (ibid.). Real realism is right to see that the ontological aspect of reality is not human conceptual fabrications. However, it is still a long way from a satisfying view. For Kitcher sometimes seems to confuse multiple levels of social reality (and truth) in the world with the existence of Reality (and Truth).

Maps, one of Kitcher's own examples, would serve as a case in point. ${ }^{14}$ I am willing to agree that we humans live in one and the same world. But that by no means undermines the sense in which the fact that the world maps we use vary in accordance with the areas we live in might affect the way the world is for us. World maps in Europe puts Europe at their centre. In the Japanese version of world map, however, Japan and its neighbouring areas are put at its centre. More striking would be the world maps employed in the southern hemisphere countries such as Australia. Their world maps are upside down. Upside down? It is possible to say so only when watched from the point of view of northern hemisphere countries' world maps. Needless to say, this is not to imply that different world maps change the material structure of the world. Yet, there is a sense in which no world maps existing in this world are the purely accurate representation of the world. It is to be noted that there exists no description of the world that can be free from the reference to (human) experience. The point here is, as Brandom says, that "nothing in the way the world is privileges one of those reference classes" (p. 116). Viewed in this way, it is warranted to think that different descriptions of the "same" world may alter our dealings with the world. This is the kernel of the thesis I want to put forward, that the notion of representation or correspondence is intrinsically normative. It goes without saying that different descriptions are subject to comparison, negotiation, and criticism and, as a result, it may turn out that some are better than others. Yet, the fact that no world map changes the physical structure of the world never assures us that an American version of world map is unconditionally to be used as the definitive version of the world. Even though different world maps do not alter the physical side of the world, they might affect our perceptions of it somehow or other precisely because any representation is normative. Analytic social epistemology misses this constitutive (and historical) character of reality and truth. This is reflected in its insensibility to the relevance of the institutional structures in the formation, transmission, and dissemination of knowledge that cannot be ruled out in a fine-grained analysis of education.

\section{A Tentative Suggestion}

I conclude with a reflection on the-as yet limited-implications of analytic social epistemology for the discourse in the philosophy of education in particular and in education studies more generally. These basic flaws of analytic social epistemology examined in the previous section are the main obstacles to making a richer contribution to the philosophical analysis of education. The fear of analytic philosophy's idiosyncratic, individualist inclination in the trap of which analytic social epistemology is still caught could be defused by taking more seriously some of the fruits of Steve Fuller's "sociological” social epistemology that

${ }^{14}$ The argument in this paragraph was originally developed in Misawa, 2012. 
itself remains to be fully developed. For analytic social epistemology and Fuller's social epistemology constitute a wheel in the carriage of a full-blooded social epistemology as of new relevance to social practices like education.

\section{References}

Almeder, R. (1998). Harmless Naturalism: The Limits of Science and the Nature of Philosophy. Chicago, Ill: Open Court.

BonJour, L. (1985). The Structure of Empirical Knowledge. Cambridge, MA: Harvard University Press.

BonJour, L. (1992). Externalism/Internalism. In J. Dancy and E. Sosa (Eds.), A Companion to Epistemology, Oxford: Blackwell.

BonJour, L. (2002). Epistemology: Classic Problems and Contemporary Responses. Lanham, Md: Rowman \& Littlefield.

Brandom, R. (2000). Articulating Reasons: An Introduction to Inferentialism. Cambridge, MA: Harvard University Press.

Chisholm, R. (1989). Theory of Knowledge. (Third ed.), Englewood Cliffs: N. J., Prentice-Hall.

Dancy, J. (1985). An Introduction to Contemporary Epistemology. Oxford: Blackwell.

De Caro, M., \& Macarthur, D. (2004). Introduction: The Nature of Naturalism. In M. De Caro and D. Macarthur (Eds.), Naturalism in Question. Cambridge, MA: Harvard University Press.

Elgin, C. (2006). From Knowledge to Understanding. In S. Hetherington (ed.). Epistemology Futures. Oxford: Oxford University Press.

Fuller, S. (2007). The Knowledge Book: The Key Concepts in Philosophy, Science and Culture. Montreal: McGill-Queen's University Press.

Goldman, A. (1998). Education and Social Epistemology. In A. Rorty (ed.) Philosophers on Education: Historical Perspectives. New York: Routledge. http://dx.doi.org/10.1093/0198238207.001.0001

Goldman, A. (1999). Knowledge in a Social World, Oxford: Clarendon Press.

Goldman, A. (2002). Pathways to Knowledge: Private and Public. Oxford: Oxford University Press.

Goldman, A. (2006). Social Epistemology. In the on-line Stanford Encylopedia of Philosophy. Retrieved from http://plato.stanford.edu/entries/epistemology-social/

Greco, J. (1999). Introduction: What is Epistemology?. In J. Greco and E. Sosa (Eds.), The Blackwell Guide to Epistemology. Malden, MA: Blackwell Publishers.

Iseda, T. (1997). Can Epistemology be Social?: A Review of Recent Attempts in Social 
Epistemology. Philosophy and History of Science, Kyoto University, 18. Retrieved from http://www.bun.kyoto-u.ac.jp/phisci/Newsletters/newslet_18.html.

Kim, J. (2000). What is “Naturalized Epistemology”?. In E. Sosa, J. Kim and M. McGrath (Eds.), Epistemology: An Anthology. Malden, MA: Blackwell Publishers.

Kitcher, P. (1994). Contrasting Conceptions of Social Epistemology. In F. Schmitt (Ed.), Socializing Epistemology: The Social Dimensions of Knowledge. Lanham, Md: Rowman \& Littlefield Publishers.

Kitcher, P. (2002). Vertistic Value and the Project of Social Epistemology. Philosophy and Phenomenological Research, 191-198. http://dx.doi.org/10.1111/j.1933-1592.2002.tb00152.x

Misawa, K. (2011). The Hirst-Carr Debate Revisited: Beyond the Theory-Practice Dichotomy. $\begin{array}{llll}\text { Journal of Philosophy of } & \text { Education, } & \text { 45(4), }\end{array}$ http://dx.doi.org/10.1111/j.1467-9752.2011.00830.x

Misawa, K. (2012). In Search of a Meeting of a Micro Perspectivist Stance and Macro Forms of Social Justice: A Response to Paul Standish, Culture and Subjectivity in Translation (Proceedings of the 5th International Symposium between the Graduate School of Education, Kyoto University (Japan), and the Institute of Education, University of London (UK)), pp. 43-47.

Putnam, H. (2004). Ethics without Ontology. Cambridge, MA: Harvard University Press.

Quine, W. V. O. (1981). Theories and Things. Cambridge, MA: Belknap Press of Harvard University Press.

Quine, W. V. O. (1988). Epistemology Naturalized. In H. Kornblith (Ed.), Naturalizing Epistemology. Cambridge, MA: The MIT Press.

Ritola, J. (2011). Justificationist Social Epistemology and Critical Thinking. Educational Theory, 61(5), 565- 585. http://dx.doi.org/10.1111/j.1741-5446.2011.00421.x

Siegel, H. (1996). Naturalism and the Abandonment of Normativity. In W. O’Donohue and R. Kitchener (Eds.), The Philosophy of Psychology. London: Sage Publications Ltd.

Siegel, H. (2005). Truth, Thinking, Testimony and Trust: Alvin Goldman on Epistemology and Education. Philosophy and Phenomenological Research, 71(2), 345-366. http://dx.doi.org/10.1111/j.1933-1592.2005.tb00452.x 